\title{
Environmental Accounting and Environmental Costs
}

\author{
Assoc. Prof. Dr. Baki Yılmaz (Selçuk University, Turkey) \\ Ph.D. Candidate Fatma Özlem Y1lmaz (Selçuk University, Turkey) \\ Prof. Dr. Naim Ata Atabey (Selçuk University, Turkey)
}

\begin{abstract}
The result of economic improvement and growth; rapidly population increase, technologic development, rapid industrialization, extreme water, air and soil pollution bring the enviromental problems. The increase lived in the environmental problems has caused an environmental conscious emerges, roots, and spills. With environmental conscious aganist the environmental problems; in the environmental costs and environmental accounting topics significant developments appear. Environmental Accounting aims at explaining the interaction between economy and environment by the information that it produces. The main approach in understanding of environmental accounting and environmental costs are to include changes in the natural environment into the national/regional accounts or corporate balance sheet. Our this Study serves the goal of the necessity of the subject of Environmental Accounting and Environmental Costs by aiming at providing for evaluating the damages in the natural environment in our world inside the process of globalization, in both a macro and micro level, and in a social, cultural, and economical structure.
\end{abstract}

\section{Introduction}

The managements, which are an indispensible part of the economical life and produce goods and services by the aim of fulfilling the unlimited needs of individual and society, carry out their activities to reach the objectives like maximizing the profit and providing the continuity of managerial activities. Managements, in the performing process of these activities, consume the nature and the natural resources differently and leave their wastes, which are in the base of environmental problems, into the nature by their activities occurring unconsciously and irresponsibly.

The increase lived in the environmental problems has caused an environmental conscious emerges, roots, and spills. Managements, because both the effect of environmental conscious and the laws inclined towards protecting the environment and the customers' reactions, who gradually become self-aware, have been obliged to move more sensitively. Managements have to pay attention not only economical but also the social effects of the activity results that they practice depending on the principle of social responsibility. In this reason, to make investments towards protecting the environment and to develop some technologies concerning with it is a state to which managements definitely have. The determination of the effects of the costs that emerge because of environmental investments and altruisms, which managements will make, and its usability in the decisions of the administration by following it is possible with the approach of Environmental Accounting. That accountancy gains an importance together with the changes occurring in economical and technological fields has brought this profession into an effective position inside the life of society and commerce. In this point, accountancy, due to the concept of 'social responsibility' of accounting, has begun to reveal the damages that managements bring in the nature; by determining its effects, it has started to work by the goal of calculating, classifying, auditing (observing), and reporting of the costs that may come out, and at the end of these works, the concept of "Environmental Accounting" has been on the agenda.

\section{The Environment and the General Principles towards Environment}

Environment is "the general sense of the sources that the livings fulfill their vital needs directly or with operations," (Kabasakal, 1995). Environment, with its one broader definition, is "the whole of the nature and the man-made elements in the nature together with human and all other living beings," (Bulca, 1995). In the second definition concerning with environment, it is mentioned about the two dimensions of the nature: The first of them is the natural environment that, the natural environment is the environment that has not been exposed to humanity's effect and intervention and that the nature constitutes. In the result of humanity's effect and intervention on the nature, the artificial environment, which is the second dimension of the nature, has been emerged. As the artificial environment is a part of the natural environment, it is a state of the natural environment beginning to be destroyed, and it has been emerged in a result of humanity's intervention on the nature (Kirloglu and Can, 1998).

The environment that has a significant influence and a vital importance on all the living beings is an important phenomenon for managements. If we think managements are born, grow and die like all livings as well, we see managements try to function inside an environment that gives opportunities for themselves.

When we define the environment in terms of managements, the environment of managements is the system of the internal and external conditions and the effects that affects on its life of activity and its development as is for all the living beings (Yoruk, 1999). 
We cannot definitely isolate the managements, which produce goods and/or services with the aim of fulfilling the unlimited needs of individuals and society, from the environment; because, managements consume the natural sources in different ways due to their activities and use many natural sources as a raw material. During the using of these sources, the nature is negatively affected, and the hazardous wastes, which bring the environmental problems out, emerge. We can express this state in the following figure:

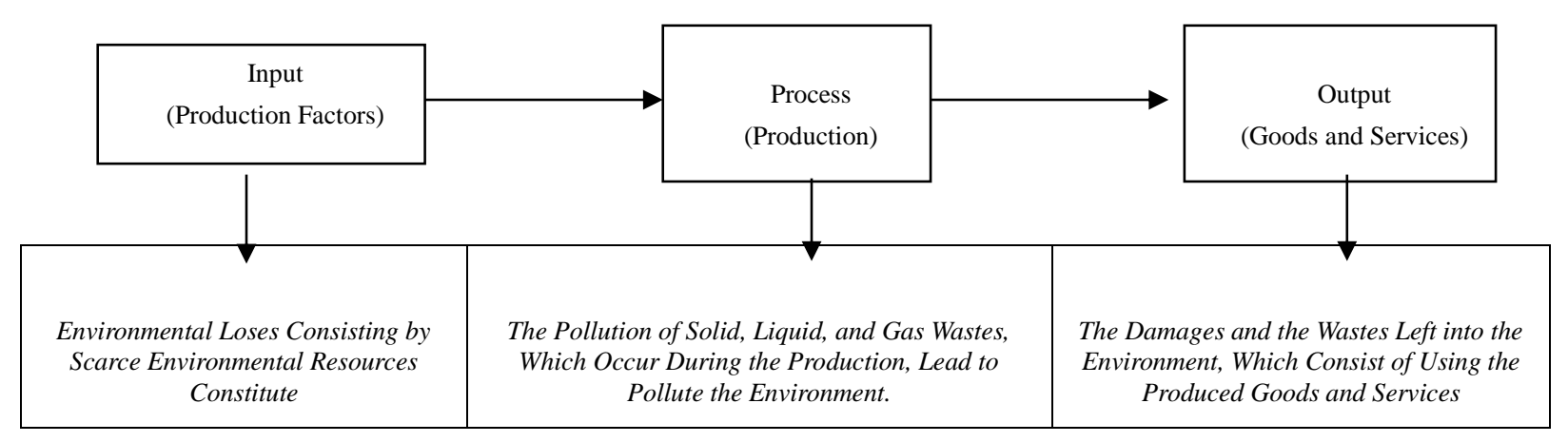

Figure 1: The Role of Managements in the Environmental Problems Source: (Kirlioglu and Can, 1998)

In the figure above, the managements continuously take some inputs from its environment and again give some outputs to its environment. Among these inputs called as production factor, there are many environmental sources, too. In the result that these sources used as an input are scarce, environmental loses emerge, and the sources decrease day by day. In addition, the pollution of solid, liquid, and gas wastes occurring during the production constitutes the base of the environmental problems.

\section{The Concept of Environmental Accounting}

Accounting, which is one of the basic functions of managements, is a science, an art, and an application that observes and determines systematically the financial-qualified events and operations occurring in the managements in the form of unit of currency and that collects and records information and documents concerned with them and that classifies and sums up meaningfully and reports and presents the results to the concerned persons and establishments by interpreting (Atabey and et al., 2001).

Accounting, as an open system, is continuously in an interaction with its environment. Accounting, due to the concept of social responsibility, is in the position of looking after the whole society's interests, not definite persons' and groups'. As an extension of the concept of social responsibility, the concept of social responsibility accounting has been born. Environmental Accounting, which is a subgroup of the social responsibility accounting, as a branch growing with the information demands suitable for the objectives of the concerned groups, stands in front of us as a field of study that includes the matters of documenting, reporting, and auditing of the expenses related to the environment.

"In recent times, as a result of the interaction between the environmental responsibility and the managerial strategies of the managements, it has needed to arise the information system of Environmental Accounting by the goal of getting the information needed in the evaluation of environmental effects and in the various managerial decisions" (Akun, 1999).

Various definitions have been made towards Environmental Accounting that is also called as "Green Accounting" in the literature of the world. Environmental Accounting:

"The definition of negative measurements of environment, and their practicing on the accounting system and its applications" (Güvemli, 1996).

"The indication of the financial-qualified events about the environment in the financial statements by accounting” (Pearce and et al., 1993 ; Aslan, 1995).

"In the accounting systems that are still practiced, especially on the cost and the profit analyses, the planning and the practicing of environmental factors" (Güvemli, 1996).

"As an example of the financial accounting measuring functions, the carefully practicing of the financial reporting and the internal and external environmental factors (related to a management)" (Gray and et al., 1993).

"The accounting of effects that are going to be emerged in the result of the using of environmental sources" (Ozbicerikli and Melek, 2002).

"It is an information system, which produces the information that explains the constituting of environmental sources, the form of using of these sources, the increases and the decreases occurring in these sources in the result of the operations of organizations and the state of the organization in terms of environment, and which conveys them to the concerned persons and establishments" (Kirlioglu and Can, 1998). 
"The recording, classifying, reporting after summing up, and interpreting of the results of the financialqualified environmental operations and events by signing with money" (Ozbicerikli and Melek, 2002).

Environmental Accounting aims at explaining the interaction between economy and environment by the information that it produces. It is seen that Environmental Accounting has the objectives lined up below, such other accounting systems (Kirlioglu and Can, 1998):

"To make up a balance sheet that indicates which level the source inventory stands on, in a definite time, and that gives its profile",

"To determine how much source stock is used, how much source come to the stock, what is added into them, and how much it changes the form in a definite period of time, and to prepare the accounts",

"To provide that the assets getting along with fixed assets become consistent, and in this way, to show it is the adding of the floating asset calculations of this year onto the balance sheet of the previous year, for every balance sheet".

Environmental Accounting has found a meaning generally in a macro level and always has been practicing like that until today. While the national applications of Environmental Accounting have been present in the resources in the literature, it has not been almost possible to meet with a work in the level of the management. The putting into practice of the ISO 9000 Quality Standards and the ISO 14000 Environmental Management and Audit Standards in the process of European Union and International Accounting Standards by the Turkish Standards Institution is an important phase practiced in this process (Kirlioglu and Can, 1998).

\section{The Environmental Costs}

The cost, in a general sense, can be defined as the whole of economical altruisms gone through to reach a goal. "As for the environmental costs are accepted as one of the costs that managements bear to present goods and services for their target groups" (Ozbicerikli, 2000). All the activities done by the managements for the environment lead to emerge the environmental costs.

Business managers, by considering the environmental suitability, will make the product diversifying and pricing, the selection of production inputs, the evaluation of the pollution prevention projects, and the waste management alternatives according to the environmental cost information, in the decisions that they will take in the managerial strategies (Akun, 1999).

Environmental costs may differ according to their shapes of formation. While some environmental costs emerge in result of the activities made for the aim of protecting the environment, some of them may arise because of their using for environmental sources (Kirlioglu and Can, 1998).

Moving from the data above, it is possible to come together the environmental costs in the dimension of environment in the three basic groups as costs of reduction, costs of using, and costs of damage (Aslan, 1995; Lutz and Munasingle, 1991).

Costs of reduction contain the costs that managements bear to prevent and reduce their environmental problems. Costs of using include the costs that a management has to go through in return for using the environmental sources. As for costs of damage, it consists of the costs of the environmental pollution and the environmental damages, which emerge in the result of the managerial activities, will load on the shoulders of managements (Ozbicerikli and Melek, 2002).

Under the light of the classification above, the cost distributions can be made the following:

\begin{tabular}{|l|l|l|}
\hline Costs of Reduction & Costs of Using & Costs of Damage \\
\hline Environmental planning & Cost of air & Air pollution \\
Control of process & Cost of water & Water pollution \\
Emission measurement devices & Cost of soil & Image pollution \\
Environmentally unharmful product-designing & Cost of noise & Punishments and Compensations \\
developing & Cost of image & Environmental Cleaning \\
Recycling designs & Cost of natural gas & Researches of Complain \\
Environmentally unharmful packing developing & Cost of petroleum & Costs of Bail and Guarantee \\
Develop the environment & Cost of coal & Sale Reductions \\
Environmental education & Cost of energy & Other Costs of Damages \\
Services of biologist and chemists & & \\
Services of environmental engineering & & \\
Environmental reports & & \\
Environmental labels & & \\
Environmental reliability & & \\
Environmental management system & & \\
Environmental audit & & \\
\hline
\end{tabular}

Table 1. The Distribution of Environmental Costs Source: (Ozbicerikli and Melek, 2002) 
The costs can be classified, grounding on various criterions. As known, we can classify the costs as fixed cost and variable cost according to the sensitiveness tied to the level of production. Fixed costs are the elements of cost, which are not tied to the level of production and not variable whatever the level of production happens. As for variable costs are the elements of cost, which are variable as tied to the level of production. Besides, it is possible to be able to observe the distribution of environmental costs in this classification.

Costs of reduction, because of its general structure, are the costs that will consist usually by the managements make investments. By a definite investment is made by a management, it is evitable that the management bears the fixed costs related to these investments. Costs of reduction are the fixed costs that managements go through, namely bear to prevent the environmental problems. In this context, here, we can examine environmental planning, environmental education, and other costs of reduction inside the class of the fixed costs. With regard to the costs of using and damaging act usually as tied to the increasing and the decreasing of the level of the management production. In addition, we can treat cost of noise and cost of energy that are of costs of using, and soil pollution, noise pollution and other costs of using and damage that are of costs of damage, inside the class of variable costs.

The environmental costs are accepted as important for a business management in the direction of the reasons below (EPA, 1995; Ozbicerikli, 2000).

"A lot of environmental costs can be considerably reduced or removed in the result of its decisions towards the matters like an investment for a more green process of production, the process of producing/manufacturing and/or the redesigning of the product rather than the short-term changes related to the activities of the business management. Because, an important part of environmental costs can be provide an added-value into the process of production, system, and product."

"Environmental costs can be followed from the general expenses account or perhaps may be ignored."

"Many companies have discovered they can compensate the environmental costs, making an income by getting the license of clean technology or selling the outage byproducts."

"The better managing of environmental costs has a big share to provide significant benefits for human's health and to increase environmental performance as much as the success of management."

"Knowing the environmental costs and the environmental performance related to the process of manufacturing and producing helps for both determining the costs and the prices of the product more truly and designing the manufacture, service, and production processes of the management more preferably in terms of environment."

"The manufacture, service, and production processes, which are more preferably for customers in terms of environment, provide a competitive advantage."

"The accounting of the environmental costs and the environmental performance can support the development of a company and all the activities of the environmental management system."

Managements have to make some self-sacrifice in both legal coercion and thematic pressures for environmental matters (Dales, 1996).

For this, managements can reduce their environmental costs, going to adopt these ways below:

- The true preference of factory location,

- The preference of technologies that pollute the environment less,

- The preference of chemical materials that pollute the environment less,

- The true preference of clean-up system,

- The reduction of the quantity of chemical materials used,

- The reduction of the quantity of wastewater,

- The reusing of waste-water,

- The recycling some materials from wastewater.

In the environmental costs in the world, especially in the sector of energy, the important progresses have been made. Particularly in the energy sector of Brazil, the concepts of social and environmental costs, which are suitable for the characteristic of the sector, have been developed. The characteristic of the environmental costs defined for this sector is the following (Tolmasguim and et al., 2000):

Costs of Audit (Costs of Control): It is the costs, which the efforts of the energy sector that are inclined toward completely or partly preventing the social and environmental effects of an investment

Costs of Reduction: It is the costs, which the energy sector makes for decreasing the results of the social and environmental effects of an investment.

Costs of Compensation: In the case that the repairing (or renovating) is not possible, it is the costs emerged from the efforts directed to balancing the social and environmental effects of an investment.

Costs of Observing: It is the costs that the energy sector makes for evaluating the social and environmental programs of the energy sector. 
Institutional Costs: It is the costs that the energy sector makes while managing the phases of planning, practicing, and managing of the social and environmental works and while preparing the works that the environmental agencies demand and while taking the environmental licenses.

Costs of Decomposition: It is the external costs that the waste social and environmental effects, which remain even after the energy sector makes real the costs of audition (control), reduction and/or compensation, do cause.

In the present day, there are two standards known environmentally. These are ISO 14000 International Environmental Management and Audit System Standards and BS (British Standard) 7750 British Environmental Management System. The Environmental Management System (EMS) is "the serial of management instruments, principles, and procedures that will protect the health of environment and human from the hazardous effects, which can be emerged from the activities, products, and services of the managements," (www.5mworld.com).

The most important advantage in the application of the Environmental Management System on the managements is the reduction that can occur in the costs of management. "The importance showed for prevention of pollution and waste-management (reduction) guides the managers continuously to look for lowercost solutions," (www.5mworld.com).

\section{Conclusion}

In the present day, the increased population, the growing cities, the local and national highways traffics, and the industrialization have exposed people to environmental problems. By the environmental problems have begun to threat the life of humanity and other livings particularly after the Revolution of Industry, the attention of the whole world has started to focus on the environmental problems. It will not be a mistake to express that the levels of humanity's sensitiveness about the environment have increased and reached a significant point today.

By the phenomenon of globalization, all the countries of the world have begun to give a place to the environmental matters in their regulations (and legislation), and they have made some regulations on the environmental regulations in both national and international level.

The environmental issues, in a micro level, have become a matter interested in the managements very closely. The managements, which make investments towards the environment and renovate their present technologies, have to constitute an effective environmental accounting system, determining the environmental costs. Under the light of the environmental costs, the integration of environmental information into the accounting system will be provided by the environmental accounting system. As for this system, it is the adaptation of the functions of the accounting, such the documenting, calculating, classifying, recording, reporting, and auditing (control), on the environmental accounting.

By the aim of being able to evaluate the damages, in micro and macro levels, which are brought into the natural environment, inside the social, cultural, and economical structure of our world in the process of globalization, the necessity of the accounting of the natural sources and of the environmental accounting today emerge. In this point, inside this thinking system, the auditing, reporting, classifying, and interpreting of the environmental investments belonging to the managements and of the cost-profitableness analyses will be surely possible only with the environmental accounting. Besides, the establishing and developing of the environmental accounting system will be tied to the environmental cost information, which will be gotten from the environmental management systems, and to the analyzing of these information.

\section{References}

- $\quad$ Akün, Lerzan, 1999. "Çevre Muhasebesi; Genel Bir Bakış”, Muhasebe Bilim Dünyası Dergisi, Cilt:1, Sayı: 1, Nisan, ss.153-155.

- Aslan, Ümmühan, 1995. Çevre Muhasebesi ve Nuh Çimento A.Ş.'nde Çevre Muhasebesi Üzerine Pilot Bir Çalışma, Yüksek Lisans Tezi, Anadolu Üniversitesi Sosyal Bilimler Enstitüsü, Eskişehir, 1995.

- Atabey, N.Ata-Parlakkaya, Raif-Alagöz, Ali, 2001. Genel Muhasebe, Dizgi Ofset, Konya.

- Bulca, Aydan, 1995. Çevre Sorunları, Cumhuriyet Dönemi Türkiye Ansiklopedisi, İletişim Yayınları, Cilt:2, İstanbul ,s.332-335.

- Dales, J.H; Çevre Sorunlarının Hukuki ve Ekonomik Temelleri, Çeviren: İ.Orhan Türköz,1996. Mobil Yayınları, İstanbul.

- EPA Project, 1995. An Introduction to Environmental Accounting as a Business Management Tool, Washington.

- Gray, Rob-Jean, Bebbington-Walters, Diana, 1993. Accounting for the Environment, Founded by the Chartered Association of Certified Accountannts, London.

- Güvemli, Oktay-Gökdeniz ,Ümit, 1996. “Çevre Muhasebesindeki Gelişmeler”, Muhasebe Bilim Dünyası Dergisi, Cilt:1, Say1:4, 1996.s.24.

- Kabasakal, Öner, 1995. "Ekonomi ve Çevre İlişkisi”, Yeni Türkiye, Mayıs, ss.330-335. 
- Kırlığlu, Hilmi-Can, Ahmet Vecdi, 1998. Çevre Muhasebesi, Değişim Yayınları, Adapazarı.

- Lutz, Ernst-Munasingle, Mohan, 1991. Accounting for the Environment, Finance\&Development, Environment Department Working Papers, World Bank, Washington D.C., March.

- Özbirecikli, Mehmet,2000. “Çevre Muhasebesi Kavramı ve Yönetsel Kararlara Katkıları”, Muhasebe ve Finansman Dergisi, Sayı:7, Temmuz 2000.s.18.

- Özbirecikli, Mehmet-Melek,Zeynep, 2002. “Çevre Muhasebesi ve Çevresel Maliyetlerin Maliyet Muhasebesi Sistemine Etkileri ve Bir Araştırma”, Muhasebe ve Finansman Dergisi, Sayı:14, Nisan, s.85.

- Pearce, David-Markandya, Anil-Barbier, B.Edward,1993. Yeşil Ekonomi İçin Mavi Kitap, Çev: Arslan, B.Kafaoğlu, T., Alan Yayıncılık, İstanbul.

- Tolmasguim, T.Mauricio-Motta, R.Seroa-Rovero, E.Lebre-Barata, M.M.Lima-Monterio, A.Guimares, 2000. Environmental Valuation for Long-Term Strategic Planning Tehe Case of the Brazilian Power Sector,

- Yörük, Nevin, 1999. Çevre Muhasebesi, İktisat, İşletme ve Finans Dergisi, Ocak, s.68.

- http://www.5mworld.com/ekim_2000/Tarih_cevreyonetim.htm 